Ляшенко А. О., аспірант*

Черкаська дослідна станція біоресурсів ІРГТ НААН

\title{
ВПЛИВ ТРИВАЛОГО ЗБЕРІГАННЯ КРІОКОНСЕРВОВАНОЇ СПЕРМИ БУГАЇВ У РІДКОМУ АЗОТІ НА ПОКАЗНИКИ ЯКОСТІ СПЕРМАТОЗОЇДІВ
}

\section{Рецензент - кандидат сільськогосподарських наук Ю. М. Сотніченко}

\begin{abstract}
Проведено дослідження показників прямолінійнопоступального руху та абсолютного показника виживаності деконсервованих сперматозоїдів бугаїв різних порід за умов довготривалого зберігання в Банку генетичних ресурсів. Встановлено високий позитивний кореляційний зв'язок між показниками рухливості та абсолютним показником виживаносmі сперматозоїдів $(r=0,89)(p<0,001)$. У результаті проведених досліджень встановлено, щчо показники рухливості та виживаності сперматозоїдів бугаӥв білоголової української, лебединської, симентальськоі та сірої української порід виявилися вищими чинного ДСТУ в середньому на $15 \%$.
\end{abstract}

Ключові слова: кріоконсервована сперма, прямолінійно-поступальний рух, виживаність, абсолютний показник виживаності сперматозоїів, довготривале зберігання, породи.

Постановка проблеми. Збереження генетичних ресурсів плідників зникаючих видів має суттєве значення у розведенні й підтриманні біорізноманіття. Повноцінна реалізація заходів зі збереження племінних ресурсів сільськогосподарських тварин забезпечується на основі створення генофондових стад у поєднанні 3 кріоконсервацією та довготривалим зберіганням генетичного матеріалу в кріобанках $[1,4]$. Важливо проводити періодичний моніторинг якості генетичних ресурсів для встановлення доцільності їх подальшого зберігання та можливості використання в селекційному процесі.

Аналіз основних досліджень і публікацій, у яких започатковано розв'язання проблеми. В умовах наднизьких температур рідкого азоту обмінні процеси в сперматозоїдах уповільнюються в мільйони разів. Перебуваючи у стані глибокого анабіозу, спермії можуть зберігати свої біологічні властивості й передавати генетичну інформацію впродовж багатьох років і навіть десятиліть. Довготривале зберігання сперми в рідкому азоті набуває все більшого значення у зв'язку з можливістю збереження порід, типів і ліній зникаючих і рідкісних тварин [5, 6]. Експериментальними дослі- дженнями окремих авторів встановлено, що глибокозаморожена сперма бугаїв може зберігати на високому рівні показники рухливості, виживаності та запліднювальної здатності до десяти років $[2,7]$. За даними Мікснера, рівень заплідненості корів від осіменіння замороженою спермою утримувався на однаковому рівні впродовж п'ятнадцяти років [3]. Визначення якісних показників сперми бугаїв різних порід, що зберігалася в рідкому азоті в Банку генетичних ресурсів понад 10 років, $\epsilon$ актуальним.

Мета і завдання досліджень. Метою наших досліджень було оцінити показники рухливості і виживаності сперматозоїдів бугаїв різних порід за умов довготривалого зберігання сперми в рідкому азоті. Завдання досліджень - провести моніторинг якості сперми бугаїв Банку генетичних ресурсів ІРГТ НААН.

Матеріал і методика проведення досліджень. У дослідженнях використовували кріоконсервовану сперму 150 -ти бугаїв 20 -ти порід. Термін зберігання досліджуваних спермодоз становив від 10 до 45 років. Нами було розділено сперму бугаїв на три групи: перша - 3 термінами зберігання 10-20 років, друга - 21-30 років і третя - 31-45 років. Оцінку показників рухливості та виживаності сперматозоїдів проводили в лабораторії з виробництва генетичної продукції сільськогосподарських тварин Головного племпідприємства Черкаського ПрАТ НВО «Прогрес» із використанням програмного комп'ютерного аналізу рухливості Sperm Vision фірми «Minitub».

Результати досліджень. За результатами досліджень встановлено, що сперма бугаїв різних термінів зберігання відповідала вимогам державного стандарту, крім сперми деяких бугаїв симентальської та бурої карпатської порід із термінами зберігання другої й третьої груп. Виживаність сперматозоїдів окремих бугаїв даних порід після розморожування становила 4 години. 3 термінами зберігання всіх трьох груп було досліджено сперму бугаїв симентальської, бурої карпатської та білоголової української порід.

* Науковий керівник - доктор сільськогосподарських наук, академік НААНУ М. І. Бащенко 
За терміну зберігання 10-20 років прямолінійнопоступальний рух (далі - ППР) і абсолютний показник виживаності (далі - АПВ) мали високі значення у бугаїв бурої карпатської та білоголової української порід. Виживаність перевищувала 5 годин. ППР сперматозоїдів бугаїв білоголової української породи становив 6,5 бала, що вище на $6 \%$, аніж ППР сперматозоїдів бугаїв бурої карпатської породи (p>0,05). Встановлено, що за терміну зберігання 21-30 років у сперматозоїдів бугаїв білоголової української породи спостерігалася найвища рухливість і АПВ; ППР сперматозоїдів був вищий за аналогічний показник інших порід у середньому на $17,2 \%(\mathrm{p}<0,05)$, а АПВ - на $44,4 \%$ ( $<0,001)$ (рис. 1). Слід вказати, що для сперматозоїдів бугаїв бурої карпатської породи першої групи характерна найвища рухливість, що більша за рухливість в інших групах у середньому на $18,9 \%$ $(\mathrm{p}<0,05)$, а АПВ вищий на 42,2\% $(\mathrm{p}<0,01)$.

Встановлено, що за терміну зберігання 21-30 років для даної породи ППР становить 4,6 бала, що нижче ніж в інших порід у середньому на 20,0 \% $(\mathrm{p}<0,05)$, а АПВ виявився нижче за ДСТУ на $5 \%$, а за АПВ в інших порід у середньому на $47,0 \%$ $(\mathrm{p}<0,01)$ (рис. 1).

Результати досліджень свідчать, що ППР і АПВ сперматозоїдів бугаїв білоголової української породи за терміну зберігання $31-45$ років вищий, ніж аналогічні показники у бугаїв бурої карпатської та симентальської порід у середньому на 20,0\% $(\mathrm{p}<0,05)$ (рис. 1). Слід зазначити, що ППР і АПВ сперматозоїдів бугаїв м'ясних порід за термінів зберігання 10-20 років виявилися вищими в середньому на $30,0 \%(p<0,05)$ у бугаїв породи шароле, ніж у бугаїв української м'ясної породи. Водночас за терміну зберігання 31-45 років, навпаки, вищими виявилися показники ППР і АПВ сперматозоїдів бугаїв української м'ясної породи в середньому на $27,0 \%(\mathrm{p}<0,05)$.

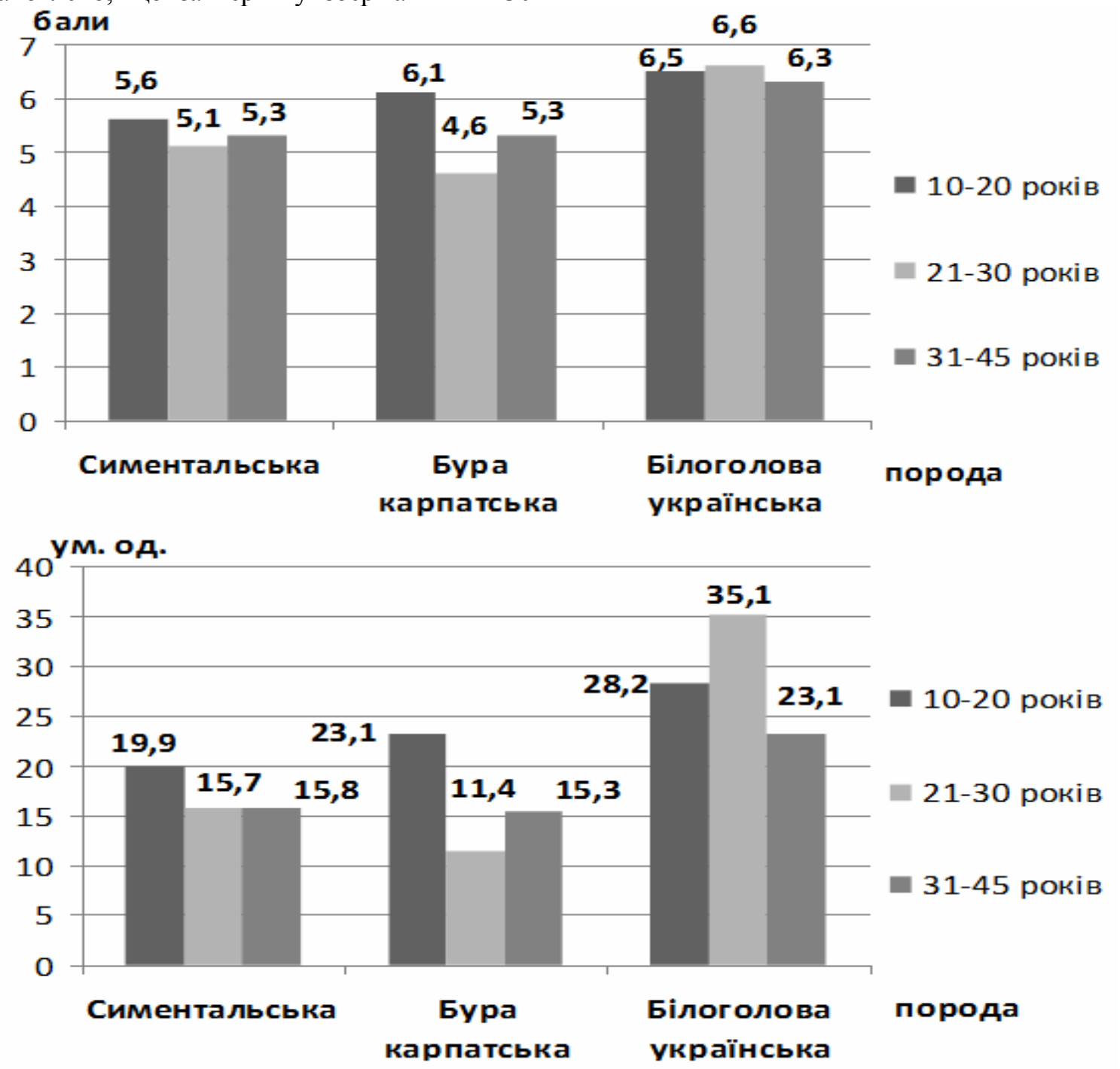

Рис. 1. ППР і АПВ сперматозоӥдів бугаӥв деяких порід у розрізі термінів зберігання (n=50) 


\section{СТОРІНКА МОЛОДОГО ВЧЕНОГО}

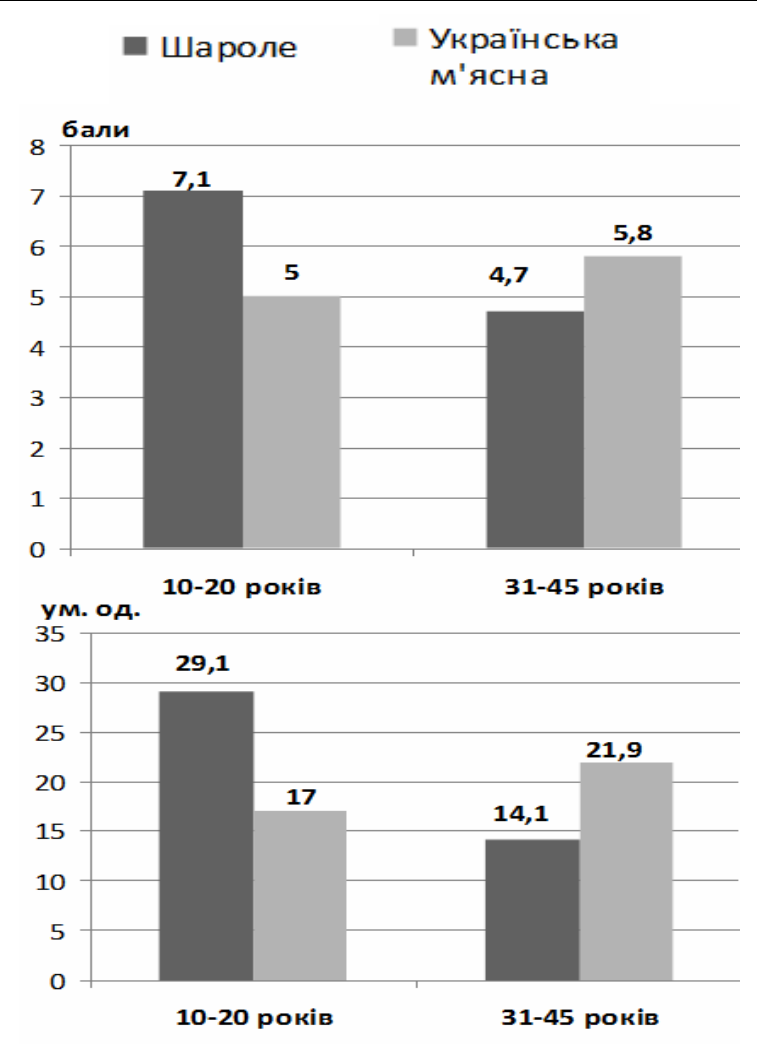

Рис. 2. ППР і АПВ сперматозоїдів бугаӥв м'ясних порід у розрізі термінів зберігання $(n=60)$

\section{БІБЛІОГРАФІЯ}

1. Буркат В. П. Банк генетичних ресурсів - основа прискореного виведення нових та збереження локальних порід / В. П. Буркат, А. П. Кругляк // Біотехнологічні, селекційні та організаційні методи відтворення, зберігання і використання генофонду тварин: Зб. наук. пр. УААН. - К. : Нац. об-ня по плем. справі у тваринництві, 1997. - С. 173-175.

2. Кругляк А. П. Перспективы научных исследований в биологии размножения и искусственного осеменения сельскохозяйственных животных / А. П. Кругляк // Розведення та штучне осіменіння великої рогатої худоби: Респ. міжв. темат. наук. зб. К. : Урожай, 1992. - Вип. 24. - С. 38-41.

3. Кругляк А. П. Якість замороженої сперми, що зберігалася понад 40 років / А. П. Кругляк // Розведення і генетика тварин: міжвід. темат. наук. зб. К. : Аграрна наука, 2001. - Вип. 34. - С. 66-67.
Встановлено, що ППР і АПВ сперматозоїдів бугаїв породи шароле першої групи вищі, ніж у сперматозоїдів бугаїв третьої групи в середньому на $42,7 \%(\mathrm{p}<0,001)$. Водночас ППР і АПВ сперматозоїдів бугаїв третьої групи української м'ясної породи вищі, ніж у сперматозоїдів бугаїв першої групи в середньому на $18,1 \%(\mathrm{p}<0,001)$ (рис. 2).

Висновки: 1. Сперма деяких бугаїв бурої карпатської, симентальської та породи шароле мали низькі показники рухливості (менше 4-х балів) i виживаності (менше 4-х годин), що, на нашу думку, є наслідком індивідуального впливу бугая.

2. Встановлено високовірогідний позитивний кореляційний зв'язок між ППР і АПВ $(r=0,89)$ $(\mathrm{p}<0,001)$ незалежно від термінів зберігання сперми бугаїв. За терміну зберігання сперми 2130 років спостерігалися найвищі значення ППР, виживаності та АПВ сперматозоїдів бугаїв білоголової української породи, а найнижчі значення - у сперматозоїдів бугаїв бурої карпатської породи.

3. Отримані результати досліджень свідчать про необхідність періодичного моніторингу кісних показників сперми вищезазначених порід для підтвердження доцільності іiі подальшого зберігання та можливості використання в селекційному процесі.

4. Методологічні аспекти збереження генофонду сільськогосподарських тварин / М. В. Зубець, В. П. Буркат, Ю. Ф. Мельник [та ін.]; наук. ред. І. В. Гузєв. К. : Аграрна наука, 2007. - 120 с.

5. Осташко Ф. И. Глубокое замораживание и длительное хранение спермы производителей / Ф. И. Осташко. - К. : Урожай, 1978. - 256 с.

6. Смирнов I. В. Стан і перспективи тривалого зберігання сперми / I. В. Смирнов // Розведення та штучне осіменіння великої рогатої худоби: республ. міжвід. темат. наук. зб. - К. : Урожай, 1978. Вип. 10. - С. 33-37.

7. Dinnyes A. Novel gamete storage / A. Dinnyes, J. Liu, T. L. Nedambale // Reproduction, Fertility and Development. - 2007. - № 19. - P. 719-731. www.publish.csiro.au/journals/rfd. 